\title{
LINGUISTIK KOGNITIF DALAM MAJAS METAFORA, METONIMI DAN SINEDOKE BAHASA JEPANG
}

\author{
Nuzulia Fitriatun Nisa' \\ Universitas Pesantren Tinggi Darul Ulum Jombang \\ nuzulia.jpg@gmail.com
}

\begin{abstract}
Abstrak
Majas merupakan sebuah fenomena bahasa yang ada di tiap bahasa di dunia. Majas dipakai untuk menjelaskan perubahan, pergeseran, dan perluasan makna kata dapat terjadi akibat perkembangan dan kemajuan yang dialami manusia sebagai pemakai bahasa. Dalam bahasa Jepang ada 3 majas yakni metafora, metonimi, sinedoke. Cabang ilmu linguistik kognitif sering dipakai untuk menjelaskan majas, karena penjabarannya yang dapat diterima oleh akal. Linguistik kognitif juga berperan untuk menjembatani kearbiteran bahasa agar sebuah makna dalam sebuah majas dapat dipahami para pembelajar.
\end{abstract}

Kata kunci: linguistik kognitif, majas, fenomena bahasa

\begin{abstract}
Figurative language is a language phenomenon that exists in every language in the world. It is used to explain changes, displacement, and can be drawn word meaning can occur development and progress made by humans as language users. There are 3 figurative languages in Japan, namely metaphor, metonymy, synecdoche. Cognitive linguistics branch is often used to explain them because of the logically explanation as a reason. Besides, cognitive linguistics also has a role as a bridge the language arbitrary in order the meaning of figurative speech can be easily understood by the readers.
\end{abstract}

Keywords: cognitive linguistics, figurative language, language phenomena

\section{A. PENDAHULUAN}

Berbicara mengenai bahasa tidak lepas dari fenomena-fenomena yang terjadi di dalam bahasa. Seiring dengan perkembangan manusia sebagai pemakainya, bahasa pun terus menerus mengalami perubahan. Perubahan tersebut menimbulkan banyak fenomena dalam bahasa. Salah satunya fenomena penggunaan bahasa dalam proses komunikasi sehari-hari. Fenomenafenomena tersebut telah banyak dikaji oleh ahli bahasa. Sejalan dengan pemikiran tersebut, Sutedi menjelaskan bahwa perubahan, pergeseran, dan perluasan makna kata dapat terjadi akibat adanya berbagai perkembangan dan kemajuan yang dialami manusia sebagai pemakai bahasa itu sendiri. Hal tersebut dapat dideskripsikan dari sudut pandang tertentu (2009:85).

Salah satu fenomena yang muncul di tiap bahasa adalah penggunaan gaya bahasa/majas(比喻). Gaya bahasa atau majas menurut Keraf adalah cara menampilkan diri 
dalam bahasa (2007). Melalui majas, dapat diperoleh efek-efek tertentu yang menunjukkan ciri khas dari pemakainya itu sendiri.

Sedangkan dalam bahasa Jepang, Morita (dalam Nurhadi, 2010:44) mendefinisikan majas (比喻 hiyu) adalah

”比喻は、その対象の特徵や状況を、意味の違うほかの語を持って連想や類推させる表現 法である。”

Majas merupakan bentuk ungkapan yang maknanya diperoleh dari analogi, hubungan pikiran untuk menunjukan karakter, keadaan atas penggunaan kata lain yang berbeda makna.

Berdasarkan kedua pendapat tersebut dapat disimpulkan bahwa majas adalah suatu bentuk ungkapan yang dapat menunjukkan karakter demi memperoleh efek memnghiasi, mempercantik suatu kata dengan kata lain secara bebas. Penggunaan majas dalam komunikasi berbahasa tidak lepas dari keinginan untuk memperindah atau memperhalus suatu bahasa. Majas sendiri berkaitan dengan perluasan makna. Menurut Sutedi (2016), perluasan makna dapat dijelaskan melalui tiga majas yakni, metafora (メタファー／隠喻), metonimi (メトニミーノ 換喻), dan sinedoke (シネクドック／提喻).

Majas memiliki banyak cara untuk mendeskripsikannya, salah satunya melalui linguistik kognitif. Namun, fenomena majas (比喻 hiyu) dalam bahasa Jepang sedikit berbeda dengan bahasa Indonesia. Untuk itu, pada artikel ini akan dibahas mengenai tiga majas yakni metafora, metonimi, dan sinedoke dalam bahasa Jepang.

\section{B. PEMBAHASAN}

1. Majas Metafora

Metafora (メタファー／隠喻) adalah majas perumpamaan untuk menyatakan sesuatu (A) digunakan untuk menyatakan sesuatu lainnya (B) atas dasar kemiripan atau titik kesamaaan (Sutedi, 2009:86). Sederhananya dapat juga dipahami dengan rumus A adalah B. A dan B memiliki kemiripan dalam arti luas yakni baik secara fisik, sifat, karakter, atau dalam hal tertentu bergantung dari sudut pandang si penutur. Untuk lebih jelasnya dapat dilihat dalam contoh berikut ini. 
(1.)文句を言えば、職場で疎んじられて、クビを切られるかもしれない。藪蛇だろう、ってことな んです。

Apabila mengeluh di tempat kerja, mungkin dapat terasing dan dapat dipecat. Hal itu dikatakan seperti bumerang kan.

(2.)草村の蛇眼のように冷たく輝っていた。

Matanya dingin memancar seperti mata ular yang bersembunyi di rerumputan.

(3.) Mereka sudah seperti anjing dan kucing.

(4.) Wanita itu bermuka dua.

Pada contoh (1) kata 藪蛇 dapat diartikan sebagai bumerang. Kata 藪蛇 disini diartikan oleh Tashiro dkk yakni, yabuhebi adalah melakukan hal yang tidak perlu (berlebihan) dan dapat menimbulkan dampak buruk bagi diri sendiri (藪蛇はよけいなことをして、かえって自分に とって悪い結果にらることです). Sebenarnya jika ditilik melalui kanji 藪 yabu berarti semak dan 蛇 hebi berarti ular, makna yang diperoleh adalah ular semak. Ular di dalam semak akan merasa kesulitan dalam bergerak, dan jika bergerak akan menyenggol batang semak yang kemungkinan besar berduri. Hal tersebut dapat membahayakan ular itu sendiri. Hal ini sama seperti boomerang, yakni sebuah senjata yang dapat kembali ke tuannya. Dalam bahasa Indonesia sering dipakai ungkapan "senjata makan tuan" yang maknanya kurang lebih sama.

Pada contoh (2) 蛇眼 dimaknai sebagai mata ular. Mata ular disini diasosiasikan dengan mata seseorang (dalam arti tatapan) yang dideskripsikan penutur. Mata ular dalam semak memiliki makna mata seorang pemburu yang sedang bersembunyi mengintai mangsanya. Pada semak yang gelap, yang terlihat hanyalah mata si ular, sedangkan tubuhnya tersembunyi di dalam semak. Selain itu, ular sering diasosiasikan dengan sifat licik, bengis dan sebagainya. Oleh karena itu, mata ular dimaknai sebagai suatu mata yang melukiskan kekejaman dan kebengisan, ini diperkuat dengan kata yang 冷たく berarti dingin. Penutur menggambarkan mata seseorang yang memiliki tatapan dingin yang menakutkan seperti mata ular. Tatapan ini bisa dimiliki seorang pembunuh yang melihat korbannya, seseorang yang sedang menginterogasi pacarnya yang selingkuh atau tatapan dosen penguji pada mahasiswanya.

Pada contoh (3) dan (4) merupakan contoh metafora dalam bahasa Indonesia. Contoh (3) Mereka sudah seperti anjing dan kucing merupakan metafora karena kata mereka dengan anjing dan kucing memiliki titik kesamaan yakni dalam segi perilaku. Jika anjing dan kucing 
bertemu pasti akan berkelahi. Perilaku inilah yang disamakan dengan perilaku "mereka" yang suka bertengka. Jadi kalimat "Mereka sudah seperti anjing dan kucing" berarti mereka yang dimaksud disini sering bertengkar/berkelahi seperti anjing dan kucing. Sebagai pembanding, dalam bahasa Jepang pun terdapat idiom neko to saru (kucing dan monyet) yang sama-sama memiliki ketidakharmonisan satu sama lain. Perbedaan idiom ini hanya karena perbedaan budaya saja, kedua idiom ini memiliki makna yang sama.

Pada contoh (4) "wanita" (A) merupakan target domain sedangkan "bermuka dua" (B) merupakan source domain. Bermuka dua bukan berarti jumlah wajahnya ada dua, namun memiliki dua sisi yang berbeda. Ungkapan ini dipakai untuk menyatakan seseorang yang berkata A kepada seseorang dan berkata sebaliknya pada musuh orang tersebut. Sehingga perkataan tersebut tidak dapt dipercaya. Makna dari kalimat "wanita itu bermuka dua" adalah ucapan dari wanita tersebut tak dapat dipercaya.

\section{Majas Metonimi}

Metonimi(メタファー／隠喻) adalah majas perumpamaan yang menyatakan sesuatu (A) digunakan untuk sesuatu lainnya (B) atas dasar berdekatan, baik secara ruang, maupun secara waktu (Sutedi, 2009:). Berdekatan yang dimaksud disini bisa berarti jaraknya cukup dekat, atau tidak berjarak sama sekali. Berdasarkan bentuk hubungan dalam majas metonimi, Sutedi membaginya ke dalam 4 kelompok yakni

1. Tempat sesuatu dan isinya

2. Bagian dan keseluruhan

3. Sebab akibat

4. Bentuk lainnya

Hal ini tentu berbeda dengan metonimi yang dikenal dalam bahasa indonesia yang sering menautkan sesuatu dengan yang lebih populer. Moeliono menafsirkan metomini sebagai gaya bahasa yang memakai nama ciri atau nama hal yang ditautkan dengan orang, barang atau hal, sebagai penggantinya(1984:3). Hal ini berarti metonimi yang dimaksud Moeliono termasuk ke dalam nomor 4, yakni penyebutan nama pencipta untuk sebuah karyanya, atau menyebutkan merek tertentu untuk sebuah produk yang sama, sedangkan Sutedi lebih menjabarkan metomini dalam empat kelompok. Untuk dapat lebih memahami majas metonimi ini dapat dilihat melalui contoh berikut ini :

(1) Sesuk aku mau nunggu manuk (Besok, saya akan menunggu burung)

(2) この問題が意見の一致を見たら、このプランでいこう 
Setelah melihat keseluruhan pendapat(mencapai kesepakatan) pada masalah ini, mari menjalankan rencana ini.

Pada contoh (1) merupakan contoh penggunaan metomini dalam bahasa Jawa. Kata nunggu yang bermakna menunggu digunakan untuk menyatakan arti menjaga. Pada kalimat "Sesuk aku mau nunggu manuk" memiliki konteks bahwa besok orang tersebut akan pergi ke sawah, karena tanaman padinya sudah akan dipanen. Untuk itu kegiatan "nunggu manuk" perlu dilakukan untuk menjaga padi dari burung-burung sehingga tanaman padi tidak rusak dan panen berlimpah. Kegiatan menunggu kedatangan burung dengan mengusir burung yang telah datang, memiliki kedekatan secara waktu. Dengan demikian frasa "nunggu manuk" dapat diartikan menjaga sawah dari burung atau mengusir burung.

Pada contoh (2) frasa 意見の一致を見る dapat dikatakan sebagai metomini berdasarkan kedekatan waktu. 意見の一致を見る dapat diartikan melihat keseluruhan pendapat, memiliki kedekatan waktu dengan mencapai mufakat(kesepakatan). Setelah melihat pendapat dari berbagai pihak, terjadi diskusi untuk mencapai suatu kesepakatan. Oleh karena itu ungkapan 意見の一致を見る dipakai untuk menyatakan telah mencapai suatu kesepakatan.

3. Majas Sinedoke

Sinedoke (シネクドック／提喻) adalah majas perumpamaan yang umum digunakan sesuatu yang khusus atau sebaliknya (Sutedi, 2016). Dalam bahasa Indonesia dikenal dua macam sinedoke, yakni pars pro toto(sebagian untuk seluruhnya), dan totem pro parte(seluruhnya untuk sebagian)

(1) 彼女に花をあげます。

(2) Seharian ini saya tidak melihat batang hidungnya.

Kata 花 hana/bunga (bersifat umum) pada contoh (1) digunakan untuk menyatakan salah satu jenis bunga yakni バラ bara/ mawar (sesuatu yang khusus). Pada pesta ulang tahun misalnya, atau pada waktu hari valentine, atau pada saat wisuda, bunga yang diberikan untuk kekasih adalah bunga mawar, atau sebuket bunga mawar. Tidak mungkin bunga yang dimksud adalah bunga bangkai, bunga sakura apalagi bunga bank. Sebaliknya pada contoh (2) menggambarkan penunjukan suatu bagian untuk mereferensikan suatu keseluruhan. Kata 
batang hidung pada kalimat "Seharian ini saya tidak melihat batang hidungnya" digunakan untuk menyatakan keseluruhan tubuh seseorang. Batang hidung merupakan bagian tubuh paling depan yang Nampak jika dilihat dari samping. Oleh karena itu batang hidung digunakan untuk ungkapan menanyakan kehadiran seseorang. Dengan demikian batang hidung pada kalimat ini termasuk ke dalam sinedoke.

\section{KESIMPULAN}

Majas metafora, metonimi, dan sinedoke banyak dipakai dalam menjelaskan fenomena yang terjadi dalam bahasa, baik menyangkut perluasan makna, hubungan antar makna, polisemi, ideom, dan sebagainya. Penjabaran melalui linguistik kognitif sering dipakai dalam menjelaskan fenomena yang tidak dapat dijelaskan melalui cabang ilmu lain. Untuk itu, pendekatan linguistik kognitif perlu dilakukan, karena penjabaran dalam linguistik kognitif bersumber pada pengalaman, pengetahuan yang telah diperoleh sehingga dapat lebih mudah diterima akal. Tentu saja sifat kearbiteran bahasa berperan penting dalam linguistik kognitif ini.

\section{REFERENSI}

Keraf, Gorys. 2007. Diksi dan Gaya Bahasa. Jakarta: PT. Gramedia Pustaka Utama.

Moeliono, Anton. 1984. Santun Berbahasa. Jakarta: PN Balai Pustaka.

Nurhadi, Didik. 2010. Kontribusi Pemahaman Budaya dalam Penafsiran Majas Metafora Bahasa Jepang, dalam jurnal INOVASI vol 16/XXII/Maret 2010, hal 43-48.

Sutedi, Dedi. 2009. Penelitian Pendidikan Bahasa Jepang: Panduan bagi Guru dan Calon Guru dalam Meneliti Bahasa Jepang dan Pengajarannya. Bandung: Humaniora.

20016. Majas/Gaya Bahasa (比喩), dalam hand out mata kuliah Linguistik Kognitif, hand out tidak diterbitkan.

Taniguchi, Kazumi. 2006. Ninchi Gengogaku: Manabi no Ekusa Saizu. Tokyo: Hitsuji Shobou.

Tashiro, Hitomi dkk. 2011. Shinkanzen Masutaa Dokkai: Nihongo Nouryoku Shiken N2. Tokyo: Suriiee network. 